\title{
Team conflict contributing to entrepreneurial learning: understanding conflict as positive within an effectual problem space
}

\section{Christina Lea Butler}

Department of Management, Kingston University Business School, Room 305, Kingston upon Thames, Surrey KT2 7LB, UK

E-mail: christina.butler@kingston.ac.uk

\author{
Karen Williams-Middleton* \\ Division for Management of Organizational Renewal and \\ Entrepreneurship, \\ Chalmers University of Technology, \\ 41296, Gothenburg, Sweden \\ E-mail: karen.williams@chalmers.se \\ *Corresponding author
}

\begin{abstract}
The impact of team conflict seems to depend upon context. Entrepreneurship literature suggests that learning from diverse perspectives in teams can contribute to entrepreneurial action (Harper 2008; West III, 2007; Williams-Middleton, 2010), while management literature has shown that conflict in teams often negatively affects creativity (Jehn et al., 2010). Recent research streams suggest that entrepreneurial learning might be better understood by applying an effectual logic perspective, instead of causal logic (Sarasvathy and Venkataraman, 2011). This causes us to question whether conflict is experienced similarly in entrepreneurial versus managerial teams. We suggest negative consequences of team conflict found in management literature may be due to the causal logic underlying this literature, and thus not readily applicable to entrepreneurial learning. Through exploring relationships between team work, team conflict, and effectuation, we propose that positive learning outcomes can emerge from experience of team conflict within an effectual and uncertain problem space.
\end{abstract}

Keywords: entrepreneurship; teams; conflict; creativity; education; learning; effectuation; logic.

Reference to this paper should be made as follows: Butler, C.L. and Williams-Middleton, K. (xxxx) 'Team conflict contributing to entrepreneurial learning: understanding conflict as positive within an effectual problem space', Int. J. Entrepreneurship and Innovation Management, Vol. X, No. Y, pp.000-000.

Biographical notes: Christina Lea Butler is a Senior Lecturer at the Department of Management in the Faculty of Business and Law at Kingston University. She researches in the area of global teams. Her current research projects include leadership of and status processes in global teams, conflict, collaboration and creativity in teams with a focus on those which are entrepreneurial, and the challenges of global workforce mobility. Her work has 
appeared in the Journal of World Business, Scandinavian Journal of Management, International Journal of Human Resource Management, Organizational Behaviour in Human Decision Processes, and Research Policy.

Karen Williams-Middleton is a Senior Lecturer at the Department of Technology Management and Economics at Chalmers University of Technology. Her research focuses on entrepreneurial identity and behaviour, and the development of entrepreneurial competency. Through her research, she investigates the venture creation process within university environments, with a specialisation in high-technology entrepreneurship in the nascent phase. Implications of her research are directed towards both educational pedagogy and research utilisation. Her previous work has been published in this journal (IJEIM), as well as the International Journal of Entrepreneurial Behavior and Research, Journal of Enterprising Communities and Journal of Small Business and Enterprise Development.

\section{Introduction}

Demand for entrepreneurial competency developed through entrepreneurship education continues to draw attention in policy discussions (OECD, 2011; World Economic Forum, 2011). While recent evaluations of entrepreneurship education have shown a general trend of focusing significantly on business and financial planning (Mwasalwiba, 2010), this focus is argued by some as insufficient in delivering the knowledge and know-how to create new firms (Gruber, 2007). Increasingly, learning in teams is suggested as important for acting entrepreneurially (Harper, 2008; West III, 2007; Williams-Middleton, 2010).

In the management literature, conflict in teams has been shown to negatively affect creativity (Jehn et al., 2010). Whilst team creativity is known to be affected by interpersonal tensions (Beersma and De Dreu, 2002; De Dreu, 2006; DeFillippi et al., 2007), the relationship is not thoroughly understood. Additionally, both the success and continuation of work teams have been shown to have a negative relationship with conflict (Hackman and Wageman, 2005). Given the interest in learning in teams for entrepreneurial action, these relationships have potentially important implications for entrepreneurial teams. However, conflict in student entrepreneurship teams has not been the subject of in-depth study (Clarysse and Moray, 2004). Research has largely been conducted with management student teams and teams working in large organisations (see for example, Jehn and Bezrukova, 2004). At the same time, there is reason to believe that entrepreneurial teams might differ in important ways from these other two types of teams.

A developing stream in the field of entrepreneurship suggests that the rationale developed by entrepreneurs in order to take action, and interact with others, might be better understood through the lens of effectual logic (Perry et al., 2011; Sarasvathy, 2008; Sarasvathy and Venkataraman, 2011). Whilst team conflict is often found to have negative consequences (see for example, De Dreu and Weingart, 2003; Jehn et al., 2010), we argue that this is due to the causal logic underlying this literature, and may not be readily applicable to entrepreneurial learning. If we were instead to build upon an effectual logic understanding, a logic through which actors transform and reconstitute their context into opportunity (Sarasvathy, 2008), conflict could be seen as a positive 
process utilised by entrepreneurial teams to enable the development of an entrepreneurial mindset. Combining theories from management and entrepreneurial literatures, we suggest that conflict within an effectual problem space could, for example, enable building argumentation for one's perspective, shape identity, and develop awareness of differences between task disputes and value disputes. Thus, changing the perspective on team conflict by taking into account differentiating aspects of the entrepreneurial context could allow for students to appreciate and utilise learning and outcomes from conflict situations.

In this conceptual paper, we build on arguments from two distinct streams of literature, those around conflict and creativity in the management work teams literature and those around effectuation and entrepreneurial method in the entrepreneurship literature, as the first steps toward the development of a model of learning through conflict in entrepreneurial teams. Our aim is to explore if there is something different about the entrepreneurial context - particularly the emergent phase of new venture creation - that would make team conflict a beneficial learning experience. This question is proposed in comparison to existent management theories regarding the impact of team conflict, in part because management theories are still the prevalent basis for many entrepreneurship educations (Dew et al., 2009; Fisher, 2012; Mwasalwiba, 2010; West III et al., 2009). Our conceptualisation is initially intended for student entrepreneurship within a university setting. We suggest the university as a natural and important setting for entrepreneurial learning (Rae, 2006; Rae and Carswell, 2001), particularly regarding calls to expand entrepreneurial emphasis beyond businenand management (Rae, 2010; Wilson, 2008). We further focus our argument at a $Q$ of interpersonal interaction (as compared to a policy perspective, or inter-organisational dynamic), as entrepreneurial learning has been argued to develop through discursive methods (Rae, 2005; Taylor and Thorpe, 2004; Williams-Middleton, 2010).

\section{The management literature perspective on team conflict and creativity}

To remain competitive, work in organisations is increasingly being carried out in teams (Tjosvold et al., 2004). There exists an extensive work teams literature which aims to understand the relationship between teamwork and its outcomes (performance in terms of meeting quality, quantity and flexibility objectives (Hoegl and Parboteeah, 2003); team satisfaction (De Dreu and Weingart, 2003)) and, sometimes, including intervening variables such as communication and, our focus in this paper, conflict. A less researched outcome is team creativity (see for example, Farh et al., 2010), defined as "the production of novel and useful ideas concerning products, services, processes, and procedures by a team of employees working together” [Shin and Zhou, (2007), p.1715]. The management literature is largely aimed at the understanding of established organisations, where control rather than creativity is the dominant paradigm. This control focus (i.e., a lack of perceived interest/need) may account for team creativity being treated as an outcome which is less important than that of performance.

For at least 45 years, one major focus of the team performance literature has been to understand the influence of team conflict on team performance (see Pondy, 1967). Two primary types of team conflict - task and relationship - have been recognised. Whereas task conflicts arise when there is disagreement among team members about "the distribution of resources, procedures and policies, and judgments and interpretation of 
facts”, relationship conflicts typically emerge over team members' differing "personal taste, political preferences, values, and interpersonal style" [De Dreu and Weingart, (2003), p.741]. Here, we confine our discussion to task conflict because creativity often emerges at the crossroads of divergent avenues of knowledge (Amabile, 1996). Empirical results for the relationship between team task conflict and team outcomes have been mixed (see for example, De Dreu, 2006; De Dreu and Weingart, 2003; Jehn, 1995; Langfred, 2007). These inconsistent findings point to the need to understand under what conditions task conflict has a positive relationship with team outcomes, including team creativity (Hülsheger et al., 2004). Indeed, as the competitive environment demands ever more from organisations (Tjosvold et al., 2004), there have been calls in the management literature for more research on team creativity (Jehn et al., 2010; Shalley et al., 2004). We focus on exploring the relationships among team task conflict, team task creativity and the following five conditions: overall level of team task conflict; changes in the level of team task conflict over a team's lifecycle; asymmetry of perceptions of team task conflict among team members; team conflict resolution strategies; and differences among types of tasks undertaken by teams.

\subsection{Level of conflict}

The (dee of minority team dissent, or team task conflict, is argued to be necessary for tearrrreativity, because it causes team members to re-evaluate the status quo, think along new lines, and in doing so adapt their approach to the task (De Dreu and West, 2001; McLeod et al., 1997). At the same time, too much task conflict may overwhelm team members with possibilities, making a coherent solution difficult (De Dreu, 2006) and increasing stress (De Dreu and Weingart, 2003; Jehn and Mannix, 2001).

As too much task conflict can overwhelm but a least a degree of task conflict is required to allow new ideas to emerge, it has been proposed that perhaps there is an optimal amount of task conflict which allows for the full creative potential of the team to be realised (De Dreu, 2006; Farh et al., 2010). For example, a study of 71 information technology China-based project teams of a Fortune 50 company, one which is also consistently ranked in the top 20 creative firms in the world, showed that task conflict has a curvilinear effect on team creativity (Farh et al., 2010). Creativity was shown to be highest at moderate levels of task conflict.

\subsection{Lifecycle}

The relationship between task conflict and team creativity may also be contingent upon when conflict occurs during a project team's life cycle. Gersick's (1988, 1989) punctuated equilibrium model suggests that team members' interactions and priorities shift significantly over the course of the team's life cycle, with the midpoint of the team's life cycle being a significant turning point betwren decisions about the task and completion of the task. Farh et al. (2010) found a onship between the amount of task conflict and creativity to hold only for the Chinese IT teams which were in the early phase of group development (Gersick, 1988, 1989). There was no relationship between level of task conflict and creativity in the later phase of group development. Building on Ford and Sullivan (2004), the authors propose that task conflict only contributes to team creativity in the early 'task decision' phase because that is when new ideas are likely to be considered. 


\subsection{Asymmetry}

The influence of task conflict on team creativity may be complicated further still by asymmetric perception of the conflict among team members. There has been considerable research across a number of areas showing that team members do have different perceptions and experiences (see for example, Galinsky et al., 2006). Jehn, et al. (2010) studied the relationship between task conflict asymmetry and team outcomes, including creativity, in 51 work groups (82\% were from engineering firms and 18\% were from investment banks). While their results show high task conflict asymmetry is negatively associated with team creativity, no si deant relationship was found between task conflict asymmetry and team performance. High task conflict asymmetry indicates that the team lacks shared cognitive structures such as mental models (Cannon-Bowers et al., 1993; Mohammed et al., 2000; Van Boven and Thompson, 2003), necessary for creative, if not routine, solutions.

\subsection{Resolution strategies}

One important way in which teams can mitigate against the negative effects of task conflict on performance is through conflict resolution processes which reduce inequity, inefficiency and ineffectiveness (Jehn and Bendersky, 2003; Marks et al., 2001; Mathieu and Schulze, 2006; Tinsley, 2001; Weingart, 1992; Williams and O’Reilly, 1988). For teams to learn, adapt and successfully meet performance goals, they need not only a shared mental model but the right one to make the right choices (Argyris, 1982; Edmondson, 1999). Behfar et al. (2008) found that consistently high performing and improving teams talked about thinking ahead in regards to how future problems might be avoided or solved. In this way, a positive group atmosphere (i.e., one with high trust, high respect and high commitment among team members) can be maintained (Jehn and Mannix, 2001).

\subsection{Task typology}

McGrath's (1984) seminal work on group interaction provides a comprehensive typology of tasks which highlights significant differences in terms of four basic processes: generation, choice, negotiation, and execution. Creative tasks are but one sub-task type which is concerned with generation, relying primarily on collaboration (rather than coordination or conflict resolution) and cognition (rather than behaviour). Empirical studies of team creativity are largely conducted on management student teams and teams working in large organisations (Jehn and Bezrukova, 2004) - for example class projects or other regular organisational work group tasks. New ventures, which resemble more open-ended project teams (in the sense that teams have more uncertain open-ended deadlines than project teams in established organisations), may require generating processes and may differently draw on choice, negotiation and execution.

In sum, from the management literature, it seems that conflict in teams is something to be avoided, or at least minimised, as it generally brings with it negative consequences for team outcomes. The exception to this general rule seems to be when teams are to generate creative outcomes. Even so, there are suggestions for limitations on the amount and type of conflict within a team, so as not to negatively impact the team's efficiency and effectiveness. Creativity seems to rank lower in importance as an outcome than 
others. The underlying research, both theoretical and empirical, is conducted, as noted previously, through a lens of management control. An element of control is essential for machine bureaucracies striving to mass produce goods and services. Increasingly though, that lens seems to bring with it team rigidities which are not suited to the rapid change and innovation that the current environment demands. We propose that there are other lenses which might provide new ways of approaching management practice including the work of teams. One of these lenses is seeing entrepreneurship as a method and thus employing effectuation.

\section{Entrepreneurship seen as a method: effectuation literature}

Sarasvathy and Venkataraman (2011) argue that entrepreneurship is a phenomenon in its own right, not a sub-category of economics, management or other such phenomena. As such, there is a distinct method of human problem solving which can be called entrepreneurial, which unleashes the potential of human behaviour. Entrepreneurship as method recognises that the creation and/or recognition of opportunities stems from the entrepreneurial process, which is inherently a process of human interaction and intersubjectivity. Some researchers argue that learning entrepreneurship is best developed through active iteration of research and practice, given certain criteria. The creation and recognition of opportunities, rather than being solely contingent upon particular characteristics or traits of an individual (Fisher, 2012; Politis, 2008; Sarasvathy and Venkataraman, 2011), can be developed by an individual as an entrepreneurial expertise. This expertise is based on decision making processes called effectuation.

\subsection{Effectuation}

Effectuation is based on empirical research which found that entrepreneurs learn to act and interact utilising decisions that are not only premised upon an outlying goal, but also on the means available to them. Effectuation is defined as processes that "take a set of means as given and focus on selecting between possible effects that can be created with that set of means" (Sarasvathy, 2001). It emphasises human action, and is seen as most applicable when human action is "the predominant factor shaping the future" [Sarasvathy, (2001), p.252]. It is presented as an alterative to processes used to select and predict actions based on a specific goal or effect, known as causation. Effectuation does not replace causation, but is applied when the space in which decisions are made are uncertain, and means for predicting the future are not necessarily available. Decision making in such contexts is recognised as differential from the more stable and predictable space of existent organisations (Sarasvathy et al., 2008).

\subsection{Effectual problem space}

Effectuation is particularly applicable to the contextual uncertainty surrounding the entrepreneurial process of emergence (Gartner et al., 1992), including new venture creation. Sarasvathy (2008, p.70) describes this context as the effectual problem space, consisting of three main elements: 
1 Knightian uncertainty - the impossibility of calculating possibilities for future consequences

2 goal ambiguity - lack of assumed or structured preferences

3 isotropy - the inability to determine upon which elements of an environment one should focus attention.

To operate in the effectual problem space, Sarasvathy argues that entrepreneurs use a logic which is non-predictive, non-teleological and non-adaptive, and explains that this is a logic of design instead of a logic of choice. She calls this effectual logic.

\subsection{Effectual logic}

Empirical research regarding effectuation has explored decision making processes of experienced or expert entrepreneurs compared to nascent or non-entrepreneurs, often contrasting the way in which effectual and causal logics are utilised (Dew et al., 2008; Read et al., 2009; Sarasvathy and Dew, 2005). Effectuation builds upon five principles which guide an individual's logic and behaviour: start with a given set of means, focus on affordable loss, focus on strategic alliances, leverage environmental contingencies, and attempt to control a future seen as unpredictable (Sarasvathy, 2008). Fundamentally, this logic suggests that individuals act from their knowledge of who they are (identity), what they know (knowledge), and who they know (network) to make guesses about uncertain future preferences in order to develop opportunities (Sarasvathy and Dew, 2005). This effectual logic is alternative to setting a predetermined goal and then thinking and acting in order to achieve said goal (i.e., causal logic). Because effectual logic is presented as a technology for guessing about uncertain future preferences (Sarasvathy and Dew, 2005), it is argued as excellent for exploiting contingencies under uncertainty, and as such, is considered more appropriate for the emergent stages of venture creation (Sarasvathy, 2001).

Effectuation research is transitioning from an adolescent to an intermediate state (Perry et al., 2011). The majority of effectuation literature is conceptual, providing proposed and debated contributions to the definition of effectuation (see for example Baron, 2009; Chiles et al., 2007; Chiles et al., 2008; Dew and Sarasvathy, 2002; Goel and Karri, 2006; Karri and Goel, 2008; Sarasvathy, 2008; Sarasvathy and Dew, 2008a, 2008b) particularly in comparison to causation. Additional research attempts to provide explanations for how effectuation may be applied (Dew et al., 2009; Read and Sarasvathy, 2005; Read et al., 2003; Sarasvathy et al., 2003; Wiltbank et al., 2006; Wiltbank et al., 2009).

There is, as yet, little effectuation research which has focused on the entrepreneurial team - whether this is understood as one 'entrepreneur' together with a set of key stakeholders, or a collective of 'entrepreneurs' founding a new venture or opportunity. Indeed, there is generally relatively little research which addresses entrepreneurial teams beyond composition (Aldrich et al., 2003), entry and exit (Forbes et al., 2006; Ucbasaran et al., 2003), and success rate (Schutjens and Wever, 2000). But while the majority of effectuation research has focused either on the cognitive processes of the 'entrepreneur' or alternatively the outcomes of entrepreneurial activity, the underlying principles of effectuation stress the importance of interaction between the 'entrepreneur' and key stakeholders (Sarasvathy, 2008). Effectuation recognises that contingencies and effects 
developed through the effectual process is not the result of one person, but the interaction of many associated actors.

Perry et al. (2011) argue that additional research should explore, among others, the relationships between effectuation and more well-established entrepreneurship and management theories. We utilise this argument as the premise for introducing effectual logic relative to the work teams literature, emphasising learning within entrepreneurial teams. We argue that the work of Sarasvathy and others provides both a basis for why the problem space is different in the emergent phase of entrepreneurship, as well as some clues as to the treatment of an interactive dynamic as part of the decision making process.

\subsection{Effectuation and work teams}

In Section 2, we reviewed the work teams literature, specifically highlighting conditions associated to team task conflict and creativity. In Section 3, we reviewed the effectuation literature specifically highlighting decision making logic for operating under uncertainty. In Table 1, we summarise the literature of work teams and effectuation, recognising that the overall logic of work team literature is causal, predictive and goal-oriented, while effectuation emphasises logic which is effectual, non-predictive and means-oriented. Next we investigate how the differentiating underlying logic of effectuation may allow for positive learning outcomes from team conflict.

Building on the rational choice work of James March, Sarasvathy and Dew argue that "the existence of ambiguous and even conflicting preferences is necessary for the successful creation of entrepreneurial novelty" (2005, p.387), and that these are more effectively drawn out through interaction with key actors, using a logic of commitment as compared to a logic of transaction. Sarasvathy states that effectuators are "more likely to build strong participatory cultures" (2001, p.261). Relating this point to the work team literature illustrates an emphasis on securing relational commitment, potentially to prevent negative relational conflict. The emphasis on high commitment also provides a strong foundation for conflict resolution.

The emphasis on commitment does require willingness to engage, but the engagement is about determining what can be, compared to what should be. We see that this may imply that different points of view or perspectives are critical to the process of determining different potential futures, and also shows that working in the effectual space perhaps deals more with an early stage of the team task lifecycle. Furthermore, determining what can be also seems to relate more to generation of tasks, rather than negotiation or execution of tasks.

Sarasvathy and Dew state that "a technology of foolishness begins with goal ambiguity as the norm, so participants in a relationship not only do not know each other's motives; they are not quite sure of their own future preferences” (2005, p.401). This places all actors involved in the entrepreneurial process in potentially conflicting perspectives, where these can also be seen as a fundamental part of the process towards decision making and action. However, in this case, conflict may be perceived more as a given of the process rather than a limitation to team work. Building on the perspective that differentiating views are a given, or even a necessity, for decision making processes seems to also limit the potential of negative outcomes based on asymmetry. 
Table 1 Review of the work teams and effectuation literatures

\begin{tabular}{|c|c|c|c|}
\hline Literature & Overall logic & Sub-themes & Key references \\
\hline \multirow[t]{10}{*}{ Work teams } & $\begin{array}{l}\text { Causal } \\
\text { Goal-oriented } \\
\text { Predictive }\end{array}$ & $\begin{array}{l}\text { Organisational competitiveness is } \\
\text { increasingly dependent on } \\
\text { teamwork }\end{array}$ & Tjosvold et al. (2004) \\
\hline & & $\begin{array}{l}\text { Teamwork outcomes of interest are } \\
\text { typically performance-focussed } \\
\text { (e.g., quality, quantity, flexibility, } \\
\text { team satisfaction and continuation, } \\
\text { success) }\end{array}$ & $\begin{array}{l}\text { De Dreu and Weingart } \\
\text { (2003), Hackman and } \\
\text { Wageman (2005) and Hoegl } \\
\text { and Parboteeah (2003) }\end{array}$ \\
\hline & & $\begin{array}{l}\text { Less of a research focus on team } \\
\text { creativity as an outcome }\end{array}$ & $\begin{array}{l}\text { Jehn et al. (2010) and Shalley } \\
\text { et al. (2004) }\end{array}$ \\
\hline & & $\begin{array}{l}\text { Research results mixed influence } \\
\text { of team conflict on team outcomes }\end{array}$ & $\begin{array}{c}\text { De Dreu (2006), De Dreu and } \\
\text { Weingart (2003), } \\
\text { Hulsheger et al. (2004) and } \\
\text { Jehn (1995); Langfred (2007) }\end{array}$ \\
\hline & & $\begin{array}{l}\text { Negative influence of team conflict } \\
\text { on creativity dominant finding }\end{array}$ & $\begin{array}{c}\text { Beersma and De Dreu (2002), } \\
\text { De Dreu (2006), } \\
\text { DeFillippi et al. (2007) and } \\
\text { Jehn et al. (2010) }\end{array}$ \\
\hline & & $\begin{array}{l}\text { Optimal amount of task conflict } \\
\text { allows full creative potential of the } \\
\text { team to be realised }\end{array}$ & $\begin{array}{l}\text { De Dreu (2006) and } \\
\text { Farh et al. (2010) }\end{array}$ \\
\hline & & $\begin{array}{l}\text { Relationship between task conflict } \\
\text { and team creativity contingent } \\
\text { upon timing of such conflict during } \\
\text { a project team's life cycle }\end{array}$ & $\begin{array}{l}\text { Farh et al.(2010) and } \\
\text { Gersick }(1988,1989)\end{array}$ \\
\hline & & $\begin{array}{l}\text { High task conflict asymmetry is } \\
\text { negatively associated with team } \\
\text { creativity }\end{array}$ & Jehn et al. (2010) \\
\hline & & $\begin{array}{l}\text { Conflict resolution processes } \\
\text { improve performance outcomes } \\
\text { such as efficiency and } \\
\text { effectiveness }\end{array}$ & $\begin{array}{l}\text { Jehn and Bendersky (2003), } \\
\text { Marks et al. (2001), Mathieu } \\
\text { and Schulze (2006), Tinsley } \\
\text { (2001), Weingart (1992) and } \\
\text { Williams and O’Reilly (1988) }\end{array}$ \\
\hline & & $\begin{array}{l}\text { There are eight different team task } \\
\text { types which draw on very different } \\
\text { underlying processes. Creativity is } \\
\text { one of the eight types. }\end{array}$ & McGrath (1984) \\
\hline \multirow[t]{2}{*}{ Effectuation } & $\begin{array}{c}\text { Effectual } \\
\text { Process-oriented } \\
\text { Means-oriented }\end{array}$ & $\begin{array}{l}\text { Management theories are still the } \\
\text { prevalent basis for many } \\
\text { entrepreneurship education }\end{array}$ & $\begin{array}{c}\text { Dew et al. (2009), Fisher } \\
\text { (2012), Mwasalwiba (2010), } \\
\text { Sarasvathy (2001) and West } \\
\text { III et al. (2009) }\end{array}$ \\
\hline & & $\begin{array}{l}\text { The environment is dynamic, } \\
\text { involving multiple interacting } \\
\text { decision makers, in contrast to the } \\
\text { static decision making towards } \\
\text { pre-existing goals }\end{array}$ & Sarasvathy (2001) \\
\hline
\end{tabular}


Table 1 Review of the work teams and effectuation literatures (continued)

\begin{tabular}{|c|c|c|c|}
\hline Literature & Overall logic & Sub-themes & Key references \\
\hline \multirow[t]{5}{*}{ Effectuation } & $\begin{array}{l}\text { Effectual } \\
\text { Process-oriented } \\
\text { Means-oriented }\end{array}$ & $\begin{array}{l}\text { Engagement in the process of } \\
\text { entrepreneurship causes } \\
\text { individuals to develop a particular } \\
\text { entrepreneurial (decision making) } \\
\text { expertise }\end{array}$ & $\begin{array}{l}\text { Dew et al. (2009), Read and } \\
\text { Sarasvathy (2005), Sarasvathy } \\
\text { (2008) and Sarasvathy and } \\
\text { Venkataraman (2011) }\end{array}$ \\
\hline & & $\begin{array}{l}\text { The firm is dependent upon the } \\
\text { design and action of the } \\
\text { 'entrepreneur' including logic } \\
\text { utilised to make decisions, in } \\
\text { collaboration with committed } \\
\text { stakeholders }\end{array}$ & $\begin{array}{l}\text { Dew et al. (2008), Fisher } \\
\text { (2012), Read et al. (2009) and } \\
\text { Sarasvathy (2001, 2004) }\end{array}$ \\
\hline & & $\begin{array}{l}\text { Effectuation involves a logic of } \\
\text { design impacting two core } \\
\text { relationships: the founder and the } \\
\text { firm, the firm and its environment }\end{array}$ & $\begin{array}{l}\text { Sarasvathy and Dew (2005) } \\
\text { and Sarasvathy et al. (2008) }\end{array}$ \\
\hline & & $\begin{array}{l}\text { Use of a non-predictive (effectual) } \\
\text { logic has impact on the size and } \\
\text { success of venture investment }\end{array}$ & $\begin{array}{l}\text { Read et al. (2009) and } \\
\text { Wiltbank et al. (2009) }\end{array}$ \\
\hline & & $\begin{array}{l}\text { When acting in uncertainty, } \\
\text { decisions are based on a preference } \\
\text { for a course of action, relating to } \\
\text { one's identity, rather than for a } \\
\text { particular outcome }\end{array}$ & Sarasvathy and Dew (2005) \\
\hline
\end{tabular}

Sarasvathy (2001, p.256) mentions Lindblom’s 'successive limited comparisons’ model as one example of an alternative to traditional models of decision making which involves using conflicting values - both between decision makers and over temporal contexts. While she positions the model as not 'causal', it has only been applied relative to policy making, not towards entrepreneurship and thus requires empirical testing. We can conclude that it is not yet understood how to apply effectuation to decision making within a team, or even if this is plausible, but it seems important to try; for example through empirical longitudinal study of nascent entrepreneurial processes, such as student-teams engaging in venture creation in university settings. If it is plausible, we then need to also explore the impact that collective effectual reasoning may have upon the 'success' of the entrepreneurial process. We recognise that there may exist challenges or limitations in building relationships between the work team literature and effectuation, as some components may not resonate with one another. Nonetheless, we have identified some aspects of effectuation that seem to alter the conditions associated to team task conflict in ways that may allow for positive outcomes for entrepreneurial learning.

\section{Interactive dynamics influencing entrepreneurial learning}

We argue that the effectual problem space and the logic utilised in the space for making decisions impact the learning achieved by the entrepreneurial teams differently than if learning in entrepreneurial teams is premised in the management literature. In order to 
explore this further, we first need to review how research proposes that entrepreneurial learning is achieved.

In his triadic model of entrepreneurial learning (Rae, 2005), David Rae proposes three main themes, and eleven subsidiary themes, contributing to entrepreneurial learning. The first main theme is labelled personal and social emergence and deals with the development of entrepreneurial identity. Subsidiary themes contributing to this include narrative construction of identity, identity as practice, tension between current and future identity, and role of the family. The second main theme is labelled contextual learning and involves situated learning and experience from engagement within a community. Subsidiary themes contributing to contextual learning include learning through immersion within industry, opportunity recognition through cultural participation, and practical theories of entrepreneurial action. The third main theme is labelled negotiated enterprise, understood as the concept that new ventures are enacted through negotiation with others. Negotiated meaning, structure and practice, changing roles over time, engagement in networks of external relationship and participation and joint enterprise are all subsidiaries of negotiated enterprise.

The majority of Rae's themes are interactive, requiring dynamics between individuals. He emphasises entrepreneurial learning, building upon narrative theories and social construction perspectives (Rae, 2005), in comparison to cognitive theories. Thus, proposing the application of a decision-making logic to help facilitate learning could be seen as inconsistent with the theoretical basis Rae suggests. However, we argue that Rae's three main themes for entrepreneurial learning align with the three core questions Sarasvathy presents as the basis for acting from an effectual logic, as follows. Personal and social emergence, which has to do with identity construction, can be associated to the first effectual question - who am I; negotiated enterprise, related to discursive engagement with one's surrounding network, aligns with the third effectual question who do I know; and contextual learning can be - what I know - as the experiential learning emerges through the entrepreneurial process. Rae's model emphasises a shift from learning about cognitively assimilated knowledge and skills to learning which is intended for action and even developed through engagement in practice (Cope and Watts, 2000; Lackeus and Williams-Middleton, 2011; Mwasalwiba, 2010) such that individuals can develop their own practical theory for acting entrepreneurially based on experience and intuition. We argue that this can be seen as consistent with Sarasvathy's processes of effectuation.

\section{The contribution conflict brings to entrepreneurial learning}

We attempt to show how arguments from two distinct streams of literature, those around conflict and creativity in the management work teams literature and those around effectuation and entrepreneurial method in the entrepreneurship literature, could provide the building blocks of an interpersonal level model of learning through conflict in entrepreneurial teams. We consider if there is something different about the entrepreneurial context, particularly the emergent phase of new venture creation, that would make team conflict a beneficial learning experience compared to the generally negative impact conflict is said to have on team performance within management studies. Our conceptualisation is initially intended for student entrepreneurship within a university setting in order to address the impact of conflict during a learning process. We 
argue that within an effectual problem space utilising effectual logic could enable learning generated from conflict within a team which would help students develop awareness of differences between task disputes and value disputes, generate opportunities through identified means and resources, and negotiate perspectives. These would in turn enable development of an entrepreneurial narrative, contributing to shaping (entrepreneurial) identity.

Typical management teams are often concerned with routine, ongoing work, or incremental innovation. This means that these teams are, from the outset, task-focused with a specific goal and related constraints. An example might be the establishment of a project team in order to develop and launch a shampoo line extension before a major competitor does. The team has some idea from the outset what the basic product is to be; what resources - financial, information, operational, and human - are available to put behind the idea; and when the product needs to be launched. This example illustrates a causal logic approach: there are already many 'givens' and the problem space has quite clear boundaries. Too many ideas might paralyse the group. As a result, management of the group's lifecycle, particularly in the early phase, is necessary. Significantly different perceptions among the team members are also likely to negatively impact the outcome (a successful shampoo brand extension) given all the 'constraints' that the team needs to manage. A shared mental model for conflict resolution becomes critical. Developing that goal-oriented shared mental model needs relationships within the team to be of good quality (e.g., high trust, high respect, and high commitment). Thus, the team is not only open to task-focused conflict, but also relational- or value-focused conflict, which we have not heretofore considered and which, in traditional management teams, tends to negatively impact team outcomes (Jehn, 1995, 1997). Personality or cultural clashes make it difficult for the team to make progress with the task and so the 'midpoint' transition (from decisions about the task to actually working on the task) and the final deadline are jeopardised.

Building on an effectual logic perspective, an entrepreneurial team growing a new venture does not initiate decision making based on a predetermined goal. Perhaps the new venture will be a brand-new hair care product or perhaps it will be a brand-new home care service. Conflicting perspectives around a task in the effectual space are not weighted with a positive or negative judgment, because, by applying an effectual logic perspective, there is not a 'supposed to be' goal that dictates preference. Instead, goals are treated as hypotheses, experience as a theory, and memory (how we did things before) as an enemy (in the sense that we are not locked in a set of decisions simply because that is what we did before) (Sarasvathv and Dew, 2005).

Applying effectual logics vacting within uncertainty creates a high commitment situation which allows conflicting perspectives to actually positively impact team performance. Different perspectives represent an introduction of different (new) means, leading to an expanding cycle of resources (Sarasvathy, 2008). Members of the new venture team consider what resources each member brings and explore what kinds of products or services these resources could be turned into, including which different ways resources can be combined or even expanded through additional social capital brought in through team members. Because the decision process is not dependent upon an existing goal, with given preferences and likelihoods, diverse and conflicting ideas about tasks can be experienced as positive and contributing to additional resources available. Relationships between team members may be different without the need to meet goaloriented outcomes. Team members negotiate among themselves and with external 
'others', allowing the team to explore options. Because there is both a lack of a predetermined goal and high commitment, entrepreneurial learning is developed as different perspectives are negotiated and team members discuss how available means may be utilised for opportunity development.

While applying an effectual logic may help to defuse potential task-conflict when making decisions, relational or value-based conflict may still present challenges to entrepreneurial teams. Because entrepreneurs operate in ambiguous or uncert (n) circumstances, they often anchor decisions relative to their 'gut' or their identity to (P) rasvathy and Dew, 2005). While diversity in teams has been shown, in certain cases, contribute to creativity, it may also lead to relational conflict, just as we discussed in regard to the management team example. However, another potential benefit of the effectual logic approach is that the entrepreneurial team will know that conflict arising in the team is likely to be relational, and can thus, from an early stage think ahead to prepare action for dealing with this type of conflict.

The effectuation perspective also brings with it the possibility of seeing interpersonal differences as a positive contribution to the new venture creation process. It is important to understand conflict simply as 'incompatible activities' which occur in both cooperative and competitive situations as an integral part of organisational life (Deutsch, 1973; Tjosvold, 2008). If there are differences in values among team members, and it would be surprising if there were not, these differences need to be understood as providing the members with additional rich resources they can draw upon. So the calling into question of one's identity as it is being developed, or during transition from one identity to another - that of the entrepreneur - could lead to a negative experience of conflict, particularly if there is not a logic in place that allows for a design focus. However, if the team is building upon an effectuation perspective, such that decision making does not begin with given and ordered preferences, then there is room for the team to help shape, through narrative, the identity.

\section{Conclusions}

We suggest the negative consequences of team conflict found in management literature may be due to the causal logic underlying this literature, and thus may not be readily applicable to entrepreneurial learning. Through exploring relationships between team work, conflict in teams and effectuation, we propose that positive learning outcomes can emerge from experience of team conflict within an effectual and uncertain problem space.

Recognising that there is a general desire to increase entrepreneurial activity, often in the form of new venture creation, and that entrepreneurship education is one main avenue for developing the competencies for new venture creation, we attempt to highlight an important differentiation between how team conflict is approached in management theory versus entrepreneurship theory. We argue that while many of the theories of organisational behaviour that stem from management theories hold for the emergent phase of entrepreneurship, some theories - in this case, theories regarding the impact of team conflict - may not hold when effectual logic is introduced. Thus, we encourage researchers to undertake in-depth longitudinal (e.g., narrative and actionresearch) studies of entrepreneurial student and new venture teams to explore conflict (i.e., incompatible activities) as it unfolds in effectual problem spaces. 


\section{Acknowledgements}

We would like to acknowledge the FORFI project which supported Christina Butler in her contribution to the article.

\section{References}

Aldrich, H.E., Carter, N.M., Ruef, M. and Kim, P.H. (2003) 'Hampered by homophily? The effects of team composition on the success of nascent entrepreneurs' organizing efforts (Summary)', in Bygrave, W.D. (Ed.): Frontiers of Entrepreneurship Research 2003, Babson College, Wellesley, MA.

Amabile, T.M. (1996) Creativity in Context, Westview, Boulder, CO.

Argyris, C. (1982) Reasoning, Learning and Action: Individual and Organizational, Jossey-Bass, San Francisco, CA.

Baron, R.A. (2009) 'Effectual versus predictive logics in entrepreneurial decision making: differences between experts and novices: Does experience in starting new ventures change the way entrepreneurs think? Perhaps, but for now, 'caution' is essential', Journal of Business Venturing, Vol. 24, No. 4, pp.310-315.

Beersma, B. and De Dreu, C.K.W. (2002) 'Integrative and distributive negotiation in small groups: effects of task structure, decision rule, and social motive', Organizational Behavior and Human Decision Processes, Vol. 87, No. 2, pp.227-252.

Behfar, K.J., Peterson, R.S., Mannix, E.A. and Trochim, M.K. (2008) 'The critical role of conflict resolution in teams: a close look at the links between conflict type, conflict management strategies, and team outcomes', Journal of Applied Psychology, Vol. 93, No. 1, pp.170-188.

Cannon-Bowers, J.A., Salas, E. and Converse, S. (1993) 'Shared mental models in expert team decision making', in Castellan Jr., N.J. (Ed.): Individual and Group Decision Making: Current Issues, Erlbaum, Hillsdale, NJ, pp.221-246.

Chiles, T.H., Bluedorn, A.C. and Gupta, V.K. (2007) 'Beyond creative destruction and entrepreneurial discovery: a radical Austrian approach to entrepreneurship', Organization Studies, Vol. 28, No. 4, pp.467-493.

Chiles, T.H., Gupta, V.K. and Bluedorn, A.C. (2008) 'On Lachmannian and effectual entrepreneurship: a rejoinder to Sarasvathy and Dew (2008)’, Organization Studies, Vol. 29, No. 2, pp.247-253.

Clarysse, B. and Moray, N. (2004) 'A process study of entrepreneurial team formation: the case of a research-based spin-off', Journal of Business Venturing, Vol. 19, No. 1, pp.55-79.

Cope, J. and Watts, G. (2000) 'Learning by doing: an exploration of experience, critical incidents and reflection in entrepreneurial learning', International Journal of Entrepreneurial Behaviour \& Research, Vol. 6, No. 3, pp.104-124.

De Dreu, C.K.W. (2006) 'When too little or too much hurts: evidence for a curvilinear relationship between task conflict and innovation in teams', Journal of Management, Vol. 32, No. 1, pp.83-107.

De Dreu, C.K.W. and Weingart, L.R. (2003) 'Task versus relationship conflict, team performance, and team member satisfaction: a meta-analysis', Journal of Applied Psychology, Vol. 88, No. 4, pp.741-749.

De Dreu, C.K.W. and West, M.A. (2001) 'Minority dissent and team innovation: the importance of participation in decision making', Journal of Applied Psychology, Vol. 86, No. 6, pp.1191-1201.

DeFillippi, R., Grabher, G. and Jones, C. (2007) 'Introduction to paradoxes of creativity: managerial and organizational challenges in the cultural economy', Journal of Organizational Behavior, Vol. 28, No. 5, pp.511-521.

Deutsch, M. (1973) The Resolution of Conflict, Yale University Press, New Haven, CT. 
Dew, N. and Sarasvathy, S.D. (2002) 'What effectuation is not: further development of an alternative to rational choice', Academy of Management Conference Denver, CO USA.

Dew, N., Read, S., Sarasvathy, S.D. and Wiltbank, R. (2008) 'Outlines of a behavioral theory of the entrepreneurial firm’, Journal of Economic Behavior \& Organization, Vol. 66, No. 1, pp.37-59.

Dew, N., Read, S., Sarasvathy, S.D. and Wiltbank, R. (2009) 'Effectual versus predictive logics in entrepreneurial decision-making: differences between experts and novices', Journal of Business Venturing, Vol. 24, No. 4, pp.287-309.

Edmondson, A. (1999) 'Psychological safety and learning behavior in work teams', Administrative Science Quarterly, Vol. 44, No. 2, pp.350-383.

Farh, J-L., Lee, C. and Farh, C.I.C. (2010) 'Task conflict and team creativity: a question of how much and when', Journal of Applied Psychology, Vol. 95, No. 6, pp.1173-1180.

Fisher, G. (2012) 'Effectuation, causation, and bricolage: a behavioral comparison of emerging theories in entrepreneurship research', Entrepreneurship Theory and Practice, Vol. 36, No. 5 , pp.1019-1051.

Forbes, D.P., Borchert, P.S., Zellmer-Bruhn, M.E. and Sapienza, H.J. (2006) 'Entrepreneurial team formation: an exploration of new member addition', Entrepreneurship Theory and Practice, Vol. 30, No. 2, pp.225-248.

Ford, C.M. and Sullivan, D.M. (2004) 'A time for everything: how the timing of novel contributions influences project team outcomes’, Journal of Organizational Behavior, Vol. 25, No. 5, pp.279-292.

Galinsky, A.D., Magee, J.C., Inesi, M.E. and Gruenfeld, D.H. (2006) 'Power and perspectives not taken’, Psychological Science, Vol. 17, No. 12, pp.1068-1074.

Gartner, W.B., Bird, B.J. and Starr, J.A. (1992) 'Acting as if: differentiating entrepreneurial from organizational behavior’, Entrepreneurship Theory and Practice, Vol. 16, No. 3, pp.13-31.

Gersick, C.J.G. (1988) 'Time and transition in work teams: toward a new model of group development', Academy of Management Journal, Vol. 31, No. 1, pp.9-41.

Gersick, C.J.G. (1989) 'Marking time: predictable transitions in task groups', Academy of Management Journal, Vol. 32, No. 2, pp.274-309.

Goel, S. and Karri, R. (2006) 'Entrepreneurs, effectual logic, and over-trust', Entrepreneurship Theory and Practice, Vol. 30, No. 4, pp.477-493.

Gruber, M. (2007) 'Uncovering the value of planning in new venture creation: a process and contingency perspective', Journal of Business Venturing, Vol. 22, No. 6, pp.782-807.

Hackman, J.R. and Wageman, R. (2005) 'A theory of team coaching', Academy of Management Review, Vol. 30, No. 2, pp.269-287.

Harper, D.A. (2008) 'Towards a theory of entrepreneurial teams', Journal of Business Venturing, Vol. 23, No. 6, pp.613-626.

Hoegl, M. and Parboteeah, K.P. (2003) 'Goal setting and team performance in innovative projects', Small Group Research, Vol. 34, No. 1, pp.3-19.

Hülsheger, U.R., Anderson, N. and Salgado, J.F. (2004) 'Team-level predictors of innovation at work: a comprehensive meta-analysis spanning three decades of research', Journal of Applied Psychology, Vol. 94, No. 5, pp.1128-1145.

Jehn, K.A. (1995) 'A multimethod examination of the benefits and detriments of intragroup conflict', Administrative Science Quarterly, Vol. 40, No. 2, pp.256-282.

Jehn, K.A. (1997) 'A qualitative analysis of conflict types and dimensions in organizational groups’, Administrative Science Quarterly, Vol. 42, pp.530-557.

Jehn, K.A. and Bendersky, C. (2003) 'Intragroup conflict in organizations: a contingency perspective on the conflict-outcome relationship', Research in Organizational Behavior, Vol. 25, pp.187-242.

Jehn, K.A. and Bezrukova, K. (2004) 'A field study of group diversity, workgroup context, and performance’, Journal of Organizational Behavior, Vol. 25, No. 6, pp.703-729. 
Jehn, K.A. and Mannix, E.A. (2001) 'The dynamic nature of conflict: a longitudinal study of intragroup conflict and group performance', Academy of Management Journal, Vol. 44, No. 2, pp.238-251.

Jehn, K.A., Rispens, S. and Thatcher, S.M.B. (2010) 'The effects of conflict asymmetry on work group and individual outcomes’, Academy of Management Journal, Vol. 53, No. 3, pp.596-616.

Karri, R. and Goel, S. (2008) 'Effectuation and over-trust: response to Sarasvathy and Dew', Entrepreneurship Theory and Practice, Vol. 32, No. 4, pp.739-748.

Lackeus, M. and Williams-Middleton, K. (2011) 'Venture creation programs: entrepreneurial education through real-life content', Babson College Entrepreneurship Research Conference, Syracuse, NY.

Langfred, C.W. (2007) 'The downside of self-management: a longitudinal study of the effects of conflict, trust, and task interdependence in self-managing teams', Academy of Management Journal, Vol. 50, No. 4, pp.885-900.

Marks, M.A., Mathieu, J.E. and Zaccaro, S.J. (2001) 'A temporally based framework and taxonomy of team processes', Academy of Management Review, Vol. 26, No. 3, pp.356-376.

Mathieu, J.E. and Schulze, W. (2006) 'The influence of team knowledge and formal plans on episodic team process-performance relationships', Academy of Management Journal, Vol. 49, No. 3, pp.605-619.

McGrath, J.E. (1984) Groups: Interaction and Performance, Prentice-Hill, Englewood Cliffs, NJ.

McLeod, P.L., Baron, R.S., Marti, M.W. and Yoon, K. (1997) 'The eyes have it: minorty influence in face-to-face and computer-mediated group discussion', Journal of Applied Psychology, Vol. 82, No. 5, pp.706-718.

Mohammed, S., Klimoski, R. and Rentsch, J.R. (2000) 'The measurement of team mental models: we have no shared schema’, Organizational Research Methods, Vol. 3, No. 2, pp.123-165.

Mwasalwiba, E.S. (2010) 'Entrepreneurship education: a review of its objectives, teaching methods, and impact indicators’, Education + Training, Vol. 52, No. 1, pp.20-47.

OECD (2011) Entrepreneurship at a Glance 2011, OECD Publishing, London, UK.

Perry, J.T., Chandler, G.N. and Markova, G. (2011) 'Entrepreneurial effectuation: a review and suggestions for future research', Entrepreneurship Theory and Practice, January, Vol. 36, No. 4, pp.1-25.

Politis, D. (2008) 'Does prior start-up experience matter for entrepreneurs' learning? A comparison between novice and habitual entrepreneurs', Journal of Small Business and Enterprise Development, Vol. 15, No. 3, pp.472-489.

Pondy, L.R. (1967) 'Organizational conflict: concepts and models', Administrative Science Quarterly, Vol. 12, No. 2, pp.296-320.

Rae, D. (2005) 'Entrepreneurial learning: a narrative-based conceptual model', Journal of Small Business and Enterprise Development, Vol. 12, No. 3, pp.323-335.

Rae, D. (2006) 'Entrepreneurial learning: a conceptual framework for technology-based enterprise', Technology Analysis \& Strategic Management, Vol. 18, No. 1, pp.39-56.

Rae, D. (2010) 'Universities and enterprise education: responding to the challenges of the new era', Journal of Small Business and Enterprise Development, Vol. 17, No. 4, pp.591-606.

Rae, D. and Carswell, M. (2001) 'Towards a conceptual understanding of entrepreneurial learning', Journal of Small Business and Enterprise Development, Vol. 8, No. 2, pp.150-158.

Read, S. and Sarasvathy, S. D. (2005) 'Knowing what to do and doing what you know: effectuation as a form of entrepreneurial expertise', Journal of Private Equity, Vol. 9, No. 1, pp.45-62.

Read, S., Song, M. and Smit, W. (2009) 'A meta-analytic review of effectuation and venture performance', Journal of Business Venturing, Vol. 24, No. 6, pp.573-587.

Read, S., Wiltbank, R. and Sarasvathy, S.D. (2003) 'What do entrepreneurs really learn from experience? The difference between expert and novice entrepreneurs', in Bygrave, W.D. (Ed.): Frontiers of Entrepreneurship Research 2003, Babson College, Wellesley, MA. 
Sarasvathy, S.D. (2001) 'Causation and effectuation: toward a theoretical shift from economic inevitability to entrepreneurial contingency', Academy of Management Review, Vol. 26, No. 2, pp.243-263.

Sarasvathy, S.D. (2004) 'Making it happen: beyond theories of the firm to theories of firm design', Entrepreneurship Theory and Practice, Vol. 28, No. 6, pp.519-531.

Sarasvathy, S.D. (2008) Effectuation: Elements of Entrepreneurial Expertise, Edward Elgar, Cheltenham, UK.

Sarasvathy, S.D. and Dew, N. (2005) 'Entrepreneurial logics for a technology of foolishness', Scandinavian Journal of Management, Vol. 21, No. 4, pp.385-406.

Sarasvathy, S.D. and Dew, N. (2008a) 'Effectuation and over-trust: debating Goel and Karri', Entrepreneurship Theory and Practice, Vol. 32, No. 4, pp.727-737.

Sarasvathy, S.D. and Dew, N. (2008b) 'Is effectuation Lachmannian? A response to Chiles, Bluedorn, and Gupta (2007)’, Organization Studies, Vol. 29, No. 2, pp.239-245.

Sarasvathy, S.D. and Venkataraman, S. (2011) 'Entrepreneurship as method: open questions for an entrepreneurial future', Entrepreneurship Theory and Practice, Vol. 35, No. 1, pp.113-135.

Sarasvathy, S.D., Dew, N., Read, S. and Wiltbank, R. (2008) 'Designing organizations that design environments: lessons from entrepreneurial expertise’, Organization Studies, Vol. 29, No. 3, pp.331-350.

Sarasvathy, S.D., Dew, N., Velamuri, R. and Venkataraman, S. (2003) 'Three views of entrepreneurial opportunity', in Acs, Z.J. and Audretsch, D.B. (Eds.): Handbook of Entrepreneurship Research, Kluwer, Dordrecht, NL.

Schutjens, V.A.J.M. and Wever, E. (2000) 'Determinants of new firm success', Papers in Regional Science, Vol. 79, No. 2, pp.135-159.

Shalley, C.E., Zhou, J. and Oldham, G.R. (2004) 'The effects of personal and contextual characteristics on creativity: where should we go from here?', Journal of Management, Vol. 30, No. 6, pp.933-958.

Shin, S.J. and Zhou, J. (2007) 'When is educational specialization heterogeneity related to creativity in research and development teams? Transformational leadership as a moderator', Journal of Applied Psychology, Vol. 92, No. 6, pp.1709-1721.

Taylor, D.W. and Thorpe, R. (2004) 'Entrepreneurial learning: a process of co-participation', Journal of Small Business and Enterprise Development, Vol. 11, No. 2, pp.203-211.

Tinsley, C. (2001) 'How negotiators get to yes: predicting the constellation of strategies used across cultures to negotiate conflict', Journal of Applied Psychology, Vol. 86, No. 4, pp.583-593.

Tjosvold, D. (2008) 'The conflict-positive organization: it depends upon us', Journal of Organizational Behavior, Vol. 29, No. 1, pp.19-28.

Tjosvold, D., Tang, M.M.L. and West, M. (2004) 'Reflexivity for team innovation in China', Group \& Organization Management, Vol. 29, No. 5, pp.540-559.

Ucbasaran, D., Lockett, A., Wright, M. and Westhead, P. (2003) 'Entrepreneurial founder teams: factors associated with member entry and exit', Entrepreneurship Theory and Practice, Vol. 28, No. 2, pp.107-127.

Van Boven, L. and Thompson, L. (2003) 'A look into the mind of the negotiator: mental models in negotiation’, Group Processes \& Intergroup Relations, Vol. 6, No. 4, pp.387-404.

Weingart, L. (1992) 'Impact of group goals, task component complexity, effort, and planning on group performance’, Journal of Applied Psychology, Vol. 77, No. 5, pp.682-693.

West III, G., Gatewood, E.J. and Shaver, K. (2009) 'Legitimacy across the university: yet another entrepreneurial challenge’, in West III, G., Gatewood, E. J. and Shaver, K. (Eds.): Handbook of University-wide Entrepreneurship Education, Edward Elgar, Cheltenham, UK, pp.1-11.

West III, G.P. (2007) 'Collective cognition: when entrepreneurial teams, not individuals, make decisions', Entrepreneurship Theory and Practice, Vol. 31, No. 1, pp.77-102.

Williams, K. and O'Reilly, C. (1988) 'Demography and diversity in organizations: a review of 40 years of research', Research in Organizational Behavior, Vol. 20, pp.77-140. 
Williams-Middleton, K. (2010) Developing Entrepreneurial Behavior: Facilitating Nascent Entrepreneurship at the University, Doctor of Philosophy Kappa, Chalmers University of Technology.

Wilson, K. (2008) 'Entrepreneurship education in Europe', in OECD (Ed.): Entrepreneurship and Higher Education, pp.1-20, OECD, Paris.

Wiltbank, R., Dew, N., Read, S. and Sarasvathy, S.D. (2006) 'What to do next? The case for non-predictive strategy’, Strategic Management Journal, Vol. 27, No. 10, pp.981-998.

Wiltbank, R., Read, S., Dew, N. and Sarasvathy, S.D. (2009) 'Prediction and control under uncertainty: outcomes in angel investing', Journal of Business Venturing, Vol. 24, No. 2, pp.116-133.

World Economic Forum (2011) 'Unlocking entrepreneurial capabilities to meet the global challenges of the 21st century: final report on the entrepreneurship education workstream', World Economic Forum Global Education Initiative, World Economic Forum. 